\title{
Blind Test of Mandibular Morphology with Sex Indicator in Subadult Mandibles
}

\author{
Test Ciego de la Morfología Mandibular como Indicador de Sexo en Mandíbulas de Subadultos \\ ","Iván Claudio Suazo Galdames; ,"*Daniela Alejandra Zavando Matamala \&"*Ricardo Luiz Smith
}

SUAZO, G. I. C.; ZAVANDO, M. D. A. \& SMITH, R. L. Blind test of mandibular morphology with sex indicator in subadult mandibles. Int. J. Morphol., 26(4):845-848, 2008.

SUMMARY: Loth \& Henneberg (2001) indicated that it was possible determine the sex with a high degree of accuracy $(81 \%)$ in mandibles of children by observing the shape of the mandibular body. The purpose of this study was to evaluate in mandibles of Brazilians subadults the proposed method consistency; were used mandibles of 33 Brazilian children between 0 and 1 year of age, known sex, belonging to the collection of skulls of the Federal University Sao Paulo (UNIFESP). We performed a blind test in two sessions by one observer based on the parameters described by Loth \& Henneberg. The results show between 57.5 and $60.5 \%$ of accuracy, being the most sensitive test for determining male (70\%) than for females $(38-46 \%)$. The results presented are lower than those reported by Loth \& Henneberg and justify the need to assess the diagnostic methods of sex in subadults in specific populations.

KEYWORD: Sexual dimorphism; Determination of sex; Subadults; Mandible.

\section{INTRODUCTION}

In humans, most of the morphological differences that allow us to classify subjects within a given sex is not seen until puberty, at this time, by action of sex hormones appear characteristics of male and female.

The qualitative or quantitative analysis, based on morphological indicators of sexual dimorphism, are therefore less reliable in children, which represents a challenge to identify skeletons with anthropological or forensic purposes, which is why it is more frequent examinations that are required molecular biology for the diagnosis of sex in children.

Have been analysed various skeletal segments to identify those that indicate a greater degree of dimorphism, in this regard Reynolds $(1945,1947)$ noted significant differences in the pelvis of individuals subadults, first in ages ranging from 0 to 1 year, expanding his remarks later to 9 years.

He was also described sexual dimorphism in the coxal articular surface of the acroiliac joint in subadults, the authors of the method reported correctly classified $74.1 \%$ of individuals analyzed (Mittler \& Sheridan, 1992).

Moreover, a study in 1034 newborns, which analyzed 34 somatic traits, circumference and width of the head, and the face diameter presented a low dimorphism (Antoszewska \& Wolanski, 1992).

Rösing (1983) notes that of all the morphological structures and regions of the skeleton there is only one that does not change size or shape after the teeth being initially developed, for this reason, one of the best indicators available for the diagnosis of sex in children is the size of tooth crowns, because the tooth size is determined by genetics. These dimensions can be analyzed through direct intraosseous dissection of the central incisor or the first molar germs, or by $\mathrm{X}$-rays analyzing, requiring both the population-specific dimensions corrections of these (Alt et al., 1998).

Loth \& Henneberg (2001) indicated that it was possible to determine the sex with a high degree of accuracy (81\%) in mandibles of children by mean observing the shape of the mandibular body. Its findings were discussed by Coqueugniot $e t$ al. (2002), who performed below those reported by Loth \& Henneberg.

Considering the need to find reliable methods for subadults of sex differences diagnosis in population-specific, the purpose of this study was to evaluate the consistencyof the method proposed by Loth \& Henneberg in a Brazilian children mandible sample in the first year of life. 


\section{MATERIAL AND METHOD}

By non-probability convenience sample, were selected 33 mandibles of known sex between 0 and 1 year of age (average 0.32 years; SD 0.33 years), belonging to the collection of skulls of the Universidad Federal de Sao Paulo (Sao Paulo, Brazil). Only felt mandibles with complete record of sex, age, date and cause of death in a good preservation state, so clearly permitted to observe the studied parameters. We excluded from this analysis the bones that had evidence of trauma, malformations or evident asymmetries.

Regarding the studied sample of 33 mandibles analyzed, 20 males and 13 females. The age distribution and frequency are found in Table I.

The mandibles were arranged on a table for observation with artificial white light, temperature and humidity conditions suitable for handling skeletons. They were classified by one trained observer in the method according to the characteristics of the symphysis and mandibular body described by Loth \& Henneberg shown in Figs. 1, 2, 3 and 4.

Each mandible was examined on two occasions in isolation of the skull to avoid the influence of other dimorphism determinants in the same, with 8-hour time difference, the observer had no prior knowledge of the distribution of the sample on the table, which was redistributed among the comments. As an observer it was handed a card on which was to collect data from their observations, which was withdrawn by another investigator for the analysis of results between each observation. Data on sex and age remained hidden to the observer throughout the analysis phase.

We calculated the level of accuracy in the determination of sex, according to the parameters outlined and established sensitivity for the diagnosis of male and female, as well as the intraobserver error.

Table I. Age and frequency distribution of the sample of 33 mandibles, UNIFESP Collection.

\begin{tabular}{|c|c|c|c|c|c|}
\hline \multicolumn{3}{|c|}{ Males (20) } & \multicolumn{3}{|c|}{ Females (13) } \\
\hline \multicolumn{2}{|c|}{ Mandible Number } & \multirow{2}{*}{$\begin{array}{l}\text { Age } \\
0.75\end{array}$} & \multicolumn{2}{|c|}{ Mandible Number } & \multirow{2}{*}{$\begin{array}{c}\text { Age } \\
0.00205479\end{array}$} \\
\hline 1 & 170 & & 1 & 171 & \\
\hline 2 & 174 & 0 & 2 & 173 & 0 \\
\hline 3 & 175 & 0 & 3 & 180 & 0 \\
\hline 4 & 176 & 0.20776256 & 4 & 209 & 0.5 \\
\hline 5 & 177 & 0.1216895 & 5 & 210 & 0.83333333 \\
\hline 6 & 179 & 0.10799087 & 6 & 215 & 0.91666667 \\
\hline 7 & 195 & 0.10799087 & 7 & 222 & 0.25 \\
\hline 8 & 196 & 0 & 8 & 242 & 0 \\
\hline 9 & 221 & 0.08333333 & 9 & 273 & 0.5 \\
\hline 10 & 254 & 0.5 & 10 & 292 & 0.00273973 \\
\hline 11 & 274 & 0 & 11 & 241 & 0.75 \\
\hline 12 & 307 & 0.16666667 & 12 & 349 & 0.08219178 \\
\hline 13 & 317 & 0.41666667 & 13 & 334 & 0.04383562 \\
\hline 14 & 376 & 0.75 & & & \\
\hline 15 & 391 & 0.16666667 & & & \\
\hline 16 & 398 & 0.83333333 & & & \\
\hline 16 & 409 & 0.41666667 & & & \\
\hline 18 & 496 & 1 & & & \\
\hline 19 & 498 & 0.5 & & & \\
\hline 20 & 499 & 0.75 & & & \\
\hline
\end{tabular}




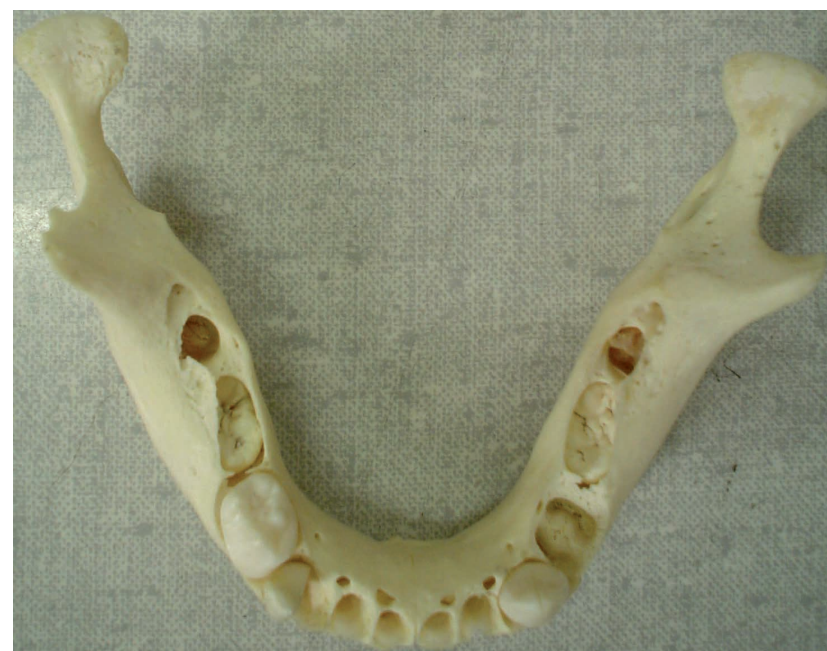

Fig. 1. Female mandible of 9 months old, superior view.

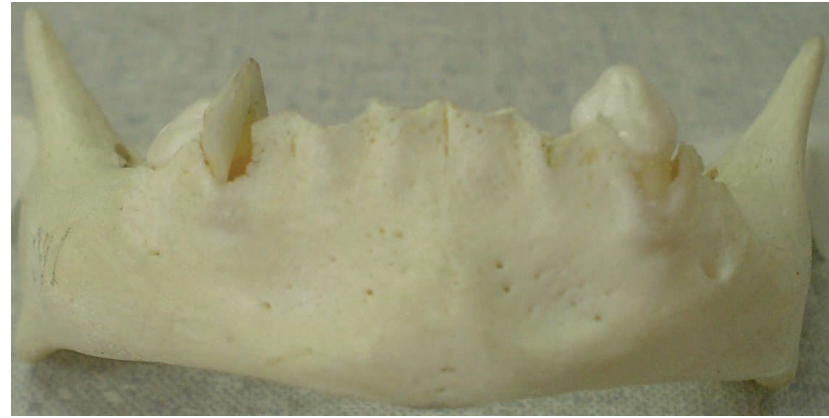

Fig. 2. Female mandible of 9 months old, anterior view.

\section{RESULTS}

The results of the sex allocation in the two sessions can be seen in Table II. If the results are considered in separate sessions there is an increase in accuracy in the second observation, $57.3 \%$ in the first and $63.6 \%$ in the second.

The sensitivity for identifying male were equal in the first and second observation, both $70 \%$. The sensitivity for female was lower and ranged from $38 \%$ in the first observation to $46 \%$ in the second.

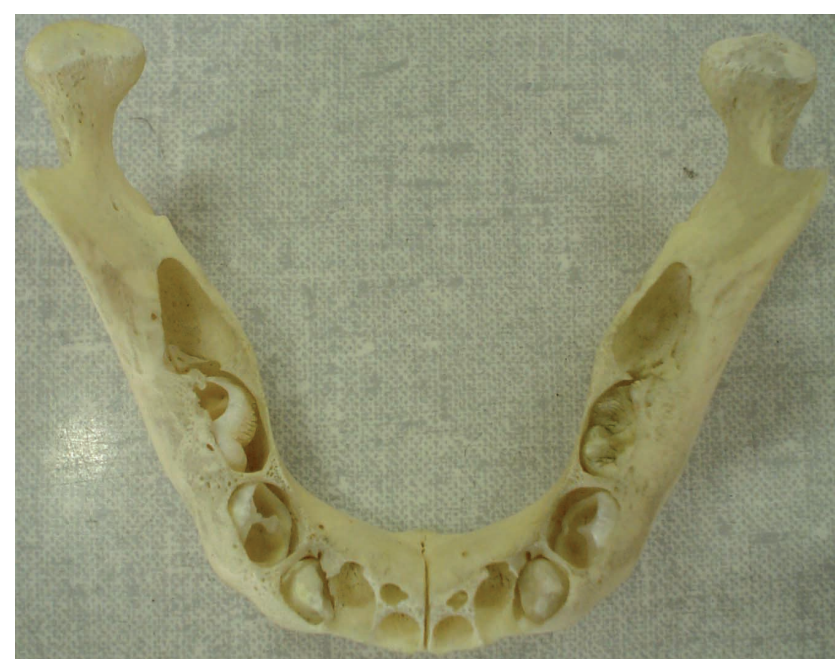

Fig. 3. Male mandible of 9 months old, superior view.

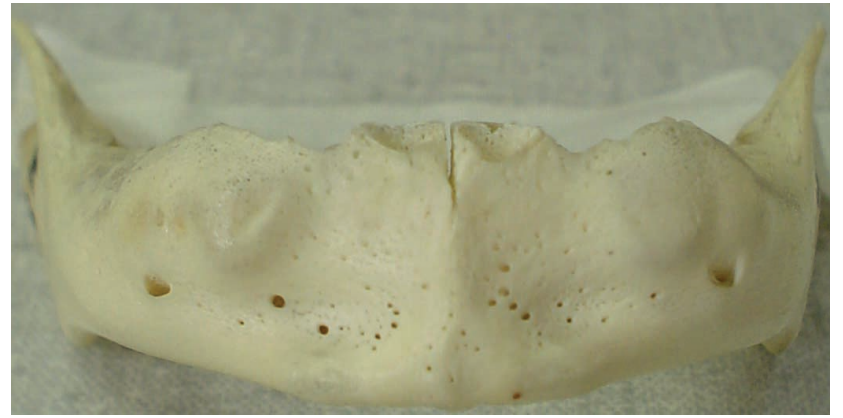

Fig. 4. Male mandible of 9 months old, anterior view.

\section{DISCUSSION}

The diagnosis of sex in subadults skeletal remnants is one of the greatest challenges of physical anthropology. We have proposed a number of methods for sex determining process, most of which includes analysis of the pelvic bones (Schutkowski, 1993).

The proposed methods in the cranial region have had a low accuracy and a difficult reproducibility. Rösing identified a number of discriminatory functions that allowed

Table II. Results of the sex allocation in 33 subadults mandibles, according to Loth \& Henneberg method.

\begin{tabular}{lccc}
\hline & $\begin{array}{c}\text { Male diagnosed } \\
\text { Correctly }\end{array}$ & $\begin{array}{c}\text { Female diagnosed } \\
\text { Correctly }\end{array}$ & Accuracy \\
\hline First observation & $14(70 \%)$ & $5(38 \%)$ & $57.5 \%$ \\
Second observation & $14(70 \%)$ & $7(46 \%)$ & $63.6 \%$ \\
\hline
\end{tabular}


classify individuals according to their sex, based on measurements taken in teeth, concluding that they were useful for subadults sex diagnosis. However, the limitations of the method are that you will need the presence of eruption tooth, implying that the osaments must be an older individual or through dissection-intraosseous regional with the obvious destruction of the maxilla or mandible, undesirable situation in the forensic anthropological practice. In the search for alternatives to solve the problem of the subadults sex diagnosis, Loth \& Henneberg proposed a simple method, based on the inspection of the shape of the mandible regions, they indicated that it was possible the correct diagnosis in $81 \%$ of cases, a situation that was questioned by various authors (Coqueugniot et al.; Scheuer, 2002).

In this study we set out to analyze the proposed method in a group of mandibles between 0 and 1 year of age at data death, even when Henneberg \& Loth listed in the original article that sexual differences can be observed in the form of the mandibular symphysis region from 7 months of age or when it has already begun the eruption of the inferior central incisor. This may be related to differences in accuracy that we find in our evaluation. It is therefore necessary to conduct extensive evaluations to the method proposed, in order to validate its use in specific populations such as that used in this study.

SUAZO, G. I. C.; ZAVANDO, M. D. A. \& SMITH, R. L. Test ciego de la morfología mandibular como indicador de sexo en mandíbulas de subadultos. Int. J. Morphol., 26(4):845-848, 2008.

RESUMEN: Loth \& Henneberg (2001) indicaron que era posible la determinación del sexo con un alto nivel de exactitud (81\%) en mandíbulas de niños, mediante la observación de la forma del cuerpo mandibular. El propósito de este estudio fue evaluar en mandíbulas de subadultos brasileños, la consistencia del método propuesto. Para ello se utilizaron 33 mandíbulas de niños brasileños de entre 0 y 1 año de edad, de sexo conocido, pertenecientes a la colección de cráneos de la Universidade Federal de São Paulo (UNIFESP), Brasil. Se realizó un test ciego en dos sesiones por un sólo observador, en base al parámetro descrito por Loth \& Henneberg. Los resultados obtenidos muestran entre un 57,5 y $60,5 \%$ de exactitud, siendo el test más sensible para la determinación del sexo masculino (70\%), que para el sexo femenino (38-46\%). Los resultados expuestos son inferiores a los reportados por Loth \& Henneberg y justifican la necesidad de evaluar los métodos de diagnóstico de sexo en subadultos, en poblaciones específicas.

PALABRAS CLAVE: Dimorfismo sexual; Determinación del sexo; Subadultos; Mandíbula.

\section{REFERENCES}

Alt, K. W.; Riemensperger, B.; Vach, W. \& Krekeler, G. Tooth root length and tooth neck diameter as indicators in sex determination of human teeth. Anthropol. Anz., 56:13144, 1998.

Antoszewska, A. \& Wolanski, N. Sexual dimorphism in newborns and adults. Stud. Hum. Ecol., 10:23-38, 1992.

Coqueugniot, H.; Giacobini, G. \& Malerba, G. L'utilisation de caracteres morphologiques dans la diagnose sexuelle des mandibules d'enfants: application à la collection ostéologique de Turín (Italie). Bull. et Mém. de la Société d'Anthropologie de Paris, 14(1-2):131-9, 2002.

Loth, S. R. \& Henneberg, M. Sexually dimorphic mandibular morphology in the first few years of life. Am. J. Phys. Anthropol., 115:179-86, 2001.

Mittler, D. M. \& Sheridan, S. G. Sex determination in subadults using auricular surface morphology: a forensic science perspective. J. Forensic Sci., 37:1068-75, 1992.
Reynolds, E. L. The bony pelvic girdle in early infancy. Am. J. Phys. Anthropol., 3(4):321-54, 1945.

Reynolds, E. L. The boney pelvis in pre-pubertal childhood. Am. J. Phys. Anthropol., 5:165-200, 1947

Rösing, F. W. Sexing immature human skeletons. J. Hum. Evol., 12:149-55, 1983.

Scheuer, L. A blind test of mandibular morphology for sexing mandibles in the first few years of life. Am. J. Phys. Anthropol., 119:189-91, 2002.

Schutkowski, H. Sex determination of infant and juvenile skeletons: I. Morphognostic features. Am. J. Phys. Anthropol., 90:199-205, 1993.

Correspondence to:

Prof. Dr. Iván Suazo Galdames

Departamento de Anatomía Normal

Universidad de Talca

Avenida Lircay s/n Oficina N`104

Talca - CHILE

Email: isuazo@utalca.cl

Received: 09-08-2008

Accepted: 22-09-2008 